\title{
KONTRUKSI SARKASME MEDIA MASSA ONLINE DI INDONESIA: JUDUL PEMBERITAAN KASUS PELECEHAN SEKSUAL REYNHARD SINAGA
}

\author{
Rai Bagus Triadi ${ }^{1}$, Euis Nicky Marnianti Suhendar ${ }^{2}$ \\ Sastra Indonesia, Universitas Pamulang ${ }^{1}$ \\ Universitas Widyatama ${ }^{2}$ \\ Surel: molikejora12@gmail.com ${ }^{1}$ \\ enickyms@gmail.com²
}

\begin{abstract}
Abstrak
Awal tahun 2020, warga Indonesia dihebohkan atas sebuah pemberitaan kasus pelecehan seksual yang dilakukan oleh salah satu warga negara Indonesia yang berdomisili di Kota Manchester, Inggris. Pada kasus ini, media massa sangat berpengaruh menambah semarak berita ini hingga viral, bahkan menggiring berbagai macam sudut pandang, baik secara psikologis, akademis, maupun sikap sosial masyarakat Indonesia. Proses pemberitaan yang dilakukan oleh media massa online di Indonesia menimbulkan banyak kesimpangsiuran, terkait jumlah korban, motif, proses, dan latar belakang pelaku pelecehan tersebut. Terlebih masalah pemilihan diksi pada judul berita pun mempunyai daya yang paling kuat untuk melakukan penggiringan publik terhadap kesimpangsiuran pemberitaan kasus tersebut. Seperti yang diketahui, hal ini didasari oleh hipotesis kebiasaan masyarakat Indonesia yang akan antusias membaca isi berita ketika judul berita itu menarik dan menimbulkan multitafsir. Sehubungan dengan ilustrasi tersebut, penelitian ini bertujuan untuk mendeskripsikan konstruksi sarkasme yang dibangun oleh media massa online di Indonesia melalui pemilihan diksi pada judul pemberitaannya. Penelitian ini menggunakan pendekatan deksriptif kualitatif dengan menggunakan teori Critical Discourse Analysis (CDA) Norman Fairclough dan teori ideologi Raymond William. Teori CDA Norman Fairclogh dalam penelitian ini digunakan untuk menginterpretasikan bentuk-bentuk' sarkasme yang terdapat pada judul pemberitaan, sedangkan teori Raymond William berupaya mengaitkan realisasi kasus kontekstual yang terjadi dengan bentuk-bentuk kesimpangsiuran proses pemberitaan di media massa online di Indonesia. Berdasarkan hasil analisis data, dapat disimpulkan bahwa terdapat bentuk sarkasme dalam pemilihan diksi judul pemberitaan kasus yang dilakukan oleh Reynhard Sinaga.
\end{abstract}

Kata kunci: Sarkasme, media online, CDA 


\begin{abstract}
Beginning in 2020 Indonesian citizens were shocked by a report about a case of sexual harassment committed by one Indonesian citizen who lives in the city of Manchester, England. The harassment was committed by someone who is male by raping the same sex with an amount that can be said to be very fantastic. In this case the mass media is very influential to add to the liveliness of this case into a viral even lead to a variety of perspectives, both psychologically, academically and social attitudes of the Indonesian people. The news process carried out by online mass media in Indonesia has a lot of confusion, both regarding the number of victims, motives, processes, both the background of the harasser. Moreover, the issue of choosing diction in the headline has the strongest power to carry out public excitement over the confusion of reporting on the case. As we know, this is based on the hypothesis of Indonesian people's habit of reading the contents when the headline is interesting and giving rise to multiple interpretations. This illustration of this research attempts to describe the construction of online mass media in Indonesia through the selection of diction on the title of a sarcastic news. This study uses a qualitative descriptive approach using Norman Fairclough's Critical Discourse Analysis theory, and Raymond William's ideological theory. The Norman Faiclogh CDA theory in this study is used to interpret the forms of sarcasm contained in the title of the news, while Raymond William's theory seeks to link the contextual case realization that occurs with the forms of confusion in the online media in Indonesia. This research uses as many as 20 news titles data from various online sites that report sexual harassment by Reynhad Sinaga. Based on the results of data analysis, it can be concluded that there are forms of sarcasm in the selection of diction on the title of case reporting conducted by Reynhard Sinaga. This was done to provide a setigma to the community about same-sex sex. Furthermore, the theory of public scrutiny hegemony carried out by news writers includes the appearance of someone who is criticized as he likes the same sex, a high level of academic education does not guarantee the religious and moral values possessed by those concerned, as well as the stigma of alma mater of same-sex rapists.
\end{abstract}

Keynote: Sarcasm, online media, CDA $\|$ miah

Pendidikan Bahasa, Sastra

Indonesia dan Daerah menyatakan bahwa perilaku seksual

\section{PENDAHULUAN}

Orientasi seksual sesama jenis hingga saat ini masih menjadi hal tabu pada masyarakat yang masih berpegang pada adat ketimuran, seperti Indonesia karena hal tersebut dinilai sebagai tindakan yang menyimpang. Berkaitan dengan hal tersebut, Douglas, Markus, (2015) yang menyimpang itu sendiri, muncul atas dasar orientasi seksual yang menyimpang. Orientasi seksual adalah kecenderungan seseorang untuk mengarahkan rasa ketertarikan, romantisme, emosional, dan seksualnya kepada pria, wanita, atau kombinasi keduanya. 
Proyeksi ini muncul atas pandangan masyarakat Indonesia yang masih kuat memegang teguh ajaran moral, etika, dan akhlak yang semuanya itu bersumber dari agama, sehingga Indonesia menentang keras adanya perilaku seksual sesama jenis yang termasuk ke dalam golongan kaum LGBT (Lesbian, Gay, Biseksual, dan Transgender) itu. Sementara itu, di beberapa negara Barat, keberadaan kaum LGBT justru dinilai sebagai orientasi seksual yang sah-sah saja sehingga tidak heran jika ada beberapa negara Barat yang sudah ada yang melegalkan pernikahan hubungan sesama jenis.

Istilah LGBT itu sendiri merupakan istilah yang digunakan sejak tahun 1990-an Sinyo (dalam American Psychological Association, 2015) menggantikan frasa "komunitas gay" karena istilah ini dinilai lebih mewakili kelompok-kelompok yang "mengisi" istilah tersebut secara lebih rinci. LGBT terdiri atas kelompok: 1) Lesbi: kelompok wanita yang secara secara fisik, emosional, dan/atau spiritual merasa tertarik dengan wanita lain; 2) Gay: kelompok pria yang secara fisik, emosional, dan/atau spiritual merasa tertarik dengan pria lain; 3) Biseksual:
kelompok orang yang secara fisik kelompok orang yang secara fisik,
emosional, dan/atau spiritual merasa tertarik baik kepada lawan jenis dan sesama jenis; 4) Transgender: kelompok orang yang merasa identitas gendernya berbeda dengan anatomi kelamin yang dimiliki, sehingga memilih/tidak memilih untuk melakukan operasi kelamin menyesuaikan dengan identitas gender yang diinginkan ketika media sebagai tolok ukur kebahasaan resmi sebuah negara.

Sehubungan dengan adanya fenomena LGBT itulah, maka hal-hal yang berkaitan tentu akan menjadi sorotan, termasuk hal-hal yang bersifat kriminal (kriminalitas) atau perbuatan yang melanggar hukum. Pernyataan ini menjadi sebuah pengantar untuk proses penjabaran penelitian ini. Singkatnya, terdapat kasus prilaku penyimpangan seksual yang berbentuk penyimpangan. Penyimpangan di sini adalah dalam bentuk pemerkosaan atau hubungan seks yang dilakukan secara pemaksaan. Kasus pemerkosaan terjadi biasanya dilakukan oleh lelaki kepada perempuan atau bahkan sebaliknya, Seperti yang telah disinggung sebelumnya, ada sebuah hal yang berbeda, yaitu pemerkosaan tersebut dilakukan oleh seorang lelaki kepada sesama lelaki.

Di Indonesia, fenomena orientasi seksual sesama jenis saja sudah dianggap sebagai suatu bentuk penyimpangan, apalagi kasus berupa pemerkosaan terhadap sesama jenis. Meskipun kejadiannya di luar negeri, yakni Inggris, tetapi pelaku pelecehan seksual itu adalah Reynhard Sinaga, heorang Warga Negara Indonesia (WNI), Schingga kasus tersebut menjadi berita yang sangat viral di Indonesia, bahkan menghebohkan dunia karena diduga korbannya berjumlah ratusan.

Kasus Reynhard Sinaga ini akhirnya marak diberitakan oleh media massa di Indonesia, mulai dari media cetak, media elektronik, hingga media online. Menurut pengamatan peneliti lebih dari satu pekan, media 
online membahas kasus ini dengan menggunakan diksi yang multitafsir dan isinya pun memuat penggiringan publik yang sangat jelas. Hal ini sejalan dengan penggiringan politik yang disampaikan oleh Tjumano (2013) bahwa kekinian dan relevansi politik adalah kekinian dan relevansi media. Kuasa semakin ditentukan oleh corak penguasaan terhadap media. Tingginya pengaruh media massa dalam menggiring opini publik mengakibatkan ideologi politik bukan lagi menjadi kekuatan yang dapat menarik para pemilih terutama ketika pemilik media sebagai praktisi politik maka penggiringan opini melalui media massa menjadi kekuatan baru. Media massa menjadi alat sebagai ajang pencitraan publik, meruntuhkan popularitas lawan politik, dan alat untuk menyerang balik kepada serangan-serangan politis.

Sejalan dengan yang dipaparkan oleh Triadi (2018) bahwa Penggunaan dan pemilihan diksi secara kias pada judul pemberitaan sering dilakukan oleh media massa di Indonesia. Hal tersebut dilakukan untuk memberikan nilai rasa atau emosi yang berbeda pada saat masyarakat membaca judul suatu pemberitaan. Judul berita dalam ruang lingkup berita secara umum dapat diibaratkan sebagai sebuah topeng yang dipasangkan oleh penulis, dapat berupa topeng yang cantik dan menarik, atau topeng yang buruk dan menyeramkan.

Penggiringan publik terhadap kasus ini dapat terlihat pada salah satu contoh judul berita yang dimuat oleh kompas.com pada tanggal 07 januari 2020, pukul 19:01 yang berjudul “Kasus Reyhard Sinaga, Waspadai 8
Ciri-ciri Predator Seksual”. Pada judul pemberitaan tersebut, terlihat sebuah diksi yang berbentuk sarkasme yaitu predator. Predator dalam KBBI $\mathrm{V}$ dimaknai sebagai binatang yang hidupnya dari memangsa binatang lain; hewan pemangsa hewan lain. Hal ini sangat kontradiktif karena Reyhard Sinaga seorang manusia, meskipun sikapnya sudah berada di luar nalar manusia normal. Selanjutnya, pada analisis Critical Discourse Analysis (CDA), terdapat bentuk relasional tekstual yang menjadikan sebuah diksi yang mampu mengubah konteks yang sangat jauh dari isi pemberitaan tersebut. Pada berita tersebut penulis menyampaikan terdapat kedelapan ciri-ciri yang menjadikan seseorang dikriteriakan sebagai predator seksual, antara lain; 1) sangat perhatian di tahap awal; 2) bahasa manipulatif; 3) membuat segala sesuatu terlihat normal; 4) playing victim; 5) mengejek pasangannya; 6) menindas pasangannya; 7) melemahkan pasangannya, dan 8) merahasiakan intriknya. Setelah peneliti melakukan studi pendahuluan pada data tersebut keterkaitan antara judul dengan isi pemberitaanya dapat dikatakan persentase keterkaitannya sangat kecil sekali, bahkan terdapat beberapa poin yang tidak ada relevansi sama sekali dengan sikap predator seksual. Jika menurut teori ideologi Raymond William penulis mejabarkan beberapa konsep yang asalnya bersifat umum menjadi sesuatu yang bersifat spesifik.

Berdasarkan latar belakang tersebut, peneliti tertarik melakukan penelitian dengan judul "Kontruksi Sarkasme Media Massa Online di 
Indonesia: Judul Pemberitaan Kasus Pelecehan Seksual Reynhad Sinaga”. Penelitian ini berupaya untuk menginterpretasikan bentuk-bentuk sarkasme yang terdapat pada judul pemberitaan kasus Reynhard Sinaga melalui teori Critical Discourse Analysis (CDA) Norman Fairclough.

Adapun penelitian terdahulu yang sama-sama menggunakan analisis Norman Fairclough yaitu "Analisis Wacana Kritis Fairclough pada Pemberitaan Selebriti di Media Daring" (Cenderamata \& Darmayanti, 2019). Akan tetapi, data penelitian tersebut berupa judul pemberitaan selebritis di media daring (online). Hasil penelitian itu menunjukkan bahwa berbagai media daring menyajikan topik berita yang sama dengan pembingkaian yang beragam, sesuai dengan motivasi dan idealism media tersebut.

Berbeda dengan penelitian terdahulu, selain menggunakan teori CDA Fairclough, penelitian berjudul "Kontruksi Sarkasme Media Massa Online di Indonesia: Judul Pemberitaan Kasus Pelecehan Seksual Reynhad Sinaga" ini juga difokuskan untuk mengaitkan realisasi kasus kontekstual yang terjadi dengan bentuk-bentuk kesimpangsiuran/proses pemberitaan di media massa online di Indonesia melalui teori ideologi Raymond William. Oleh karena itu, berdasarkan studi pendahuluan tersebut, peneliti pada penelitian ini berupaya merumuskan masalah yang akan dibahas pada penelitian ini meliputi, 1) bentuk sarkasme yang terdapat dalam judul pemberitaan Reyhard Sinaga pada media massa online di Indonesia; 2) relasional tekstual antara judul berita dan isi berita yang akhirnya proses penggiringan opini publik terjadi.

Selain melihat fenomena yang terjadi, dalam proses merumuskan masalah peneliti merujuk kepada pendapat Kress (1984) yang menyatakan from the preceding argument it is clear that rewriting is more than a mere tinkering with language. Rewriting is a shorthand term for a process which involves at least these stages: the deconstruction in text, the reconstruction of the original event, its apperception in terms of the new schema. Both writing and rewriting are practices which are firmly set in ideological structures and are expressions of them.

Berdasarkan uraian tersebut terdapat tiga unsur yang menjadi gagasan penentuan rumusan masalah. Pertama yaitu pada tahapan rereporting dan rewriting atau bisa dikatakan struktur bahasa dan ideologisasi yang beriringan, pada tahap ini penulis memilah-milah diksi yang tepat pada judul agar pembaca tertarik membaca isi dari berita tersebut; kedua, ideologi yang muncul bisa dilihat ketika konteks yang utuh terlihat pada keseluruhan teks, pada hunsur ini ideologi pro-kontra terhadap GGBT, muncul; dan ketiga, ideologi yang digunakan akan tampak ketika teks tersebut dikontruksi menggunakan struktur bahasa yang mana (pemilihan diksi dalam hal ini diksi yang memiliki bentuk sarkasme).

\section{1) Teori Bahasa dan Sarkasme}

Ansori (2017) menyatakan bahwa salah satu fungsi bahasa adalah 
sebagai kontrol sosial, yaitu kemampuan bahasa dalam mempengaruhi pikiran orang lain karena penggunaan bahasa. Pencitraan terjadi karena perluasan pengaruh yang dilakukan oleh penutur sebuah bahasa. Kalimat-kalimat yang ditulis media akan berpengaruh di masyarakat, bahkan mungkin dianggap sebuah kebenaran. Begitupula bahasa yang memiliki bentuk sarkasme, peneliti beranggapan bentuk bahasa ini akan sangat membuat sebuah hal yang samar menjadi benar di mata pembaca.

Dalam kaitan tersebut, dapat dijelaskan bahwa sarkasme adalah sejenis majas yang mengandung mengolok-olok atau sindiran pedas dengan menyakiti hati (Purwadarminta dalam Tarigan, 1990:92). Apabila dibandingkan dengan ironi dan sinisme, maka sarkasme ini lebih kasar. Menurut Badudu (1975:78), sarkasme adalah gaya sindiran terkasar. Memaki orang dengan katakata kasar dan tak sopan di telinga. Biasanya diucapkan oleh orang yang sedang marah. KBBI $\mathrm{V}$ juga mendefinisikan sarkasme adalah penggunaan kata-kata pedas untuk menyakiti hati orang lain; cemoohan atau ejekan kasar.

Heryanto (dalam Ansori, 2017) berpendapat bahasa tidak hanya dibentuk dan ditentukan, tetapi juga membentuk dan menentukan sejarah sosial. Bahasa bukan sekadar "alat" untuk mengungkapkan pikiran dan tidak mampu memenuhi kebutuhan komunikasi personal tidaklah layak jadi kekuatan pembemtuk pikiranperasaan dan suatu tata sosial yang sebelumnya tidak ada. Bagaimana proses sejarah sosial yang mendorong perubahan dari masyarakat berbahasa ke masyarakat berbahasa.

\section{2) Teori Critical Discourse Analysis (CDA) Norman Fairclough}

Terkait dengan teori Critical Discourse Analysis (CDA), Fairclough (dalam Eriyanto, 2003:288) memaparkan ada tiga dimensi analisis wacana, yaitu dimensi text, discourse practice, dan sosiocultural practice. (a) Dimensi teks (mikrostruktural) dianalisis secara linguistik, yakni dianalisis secara linguistik dengan melihat kosakata, semantik, dan sintaksis. (b) Discourse practice (mesostruktural) yaitu dimensi yang berhubungan dengan proses produksi dan konsumsi teks. (c) Sosiocultural practice (makrostruktural) adalah dimensi yang berhubungan dengan konteks di luar teks.

Ketiga dimensi tersebut selanjutnya dianalisis menggunakan tiga tahap analisis yang berbeda, yaitu sebagai berikut: (1) deskripsi digunakan untuk menganalisis teks, meliputi kohesi dan koherensi, tata bahasa, dan diksi; (2) interpretasi digunakan untuk menganalisis interpretasi teks, meliputi produksi, penyebaran, dan konsumsi teks; dan (3) eksplanasi digunakan untuk menganalisis praktik-praktik sosiokultural yang mencakup level situasional, institusional, dan sosial (Fairclough, 1995:58).

Dalam kaitan itu, Fairclough (dalam Darma, 2009:69) juga menjelaskan wacana harus dipandang secara simultan, yaitu sebagai (1) teksteks bahasa, baik lisan maupun tulisan, (2) praksis kewacanaan, yaitu 
produksi teks dan interpretasi, (3) praksis sosiokultural, yaitu perubahan-perubahan masyarakat institusi budaya yang menentukan bentuk dan makna sebuah wacana. Ketiga unsur itu, oleh Fairclough disebut "dimensi wacana", menganalisis wacana secara kritis pada hakikatnya adalah menaganalisis tiga dimensi wacana secara integral dan ketiga dimensi tersebut merupakan satu kesatuan yang tak dapat dipisahkan antara satu dengan yang lainnya.

Konsep teori ini menurut peneliti sejalan dengan konsep elemen tindak tutur wartawan yang disampaikan oleh Geofreey Leech (tahun); siapa lagi (tahun); jurnal gema online; Wibowo (2009) yang membagi menjadi tiga hal yaitu lokusi, ilokusi dan perlokusi. Adapun penjelasan konsep elemen tersebut terlihat pada tabel di bawah ini.

\section{Tabel 1}

\section{Elemen Tindak Tutur Komunikasi Wartawan}

\begin{tabular}{|l|l|}
\hline $\begin{array}{l}\text { Elemen } \\
\text { lokusi; } \\
\text { kategorisasi } \\
\text { dan ideology }\end{array}$ & $\begin{array}{l}\text { Ungkapan bahasa } \\
\text { adalah wujud } \\
\text { antroposentrisme } \\
\text { individu, yang urna } \\
\text { dilandasi oleh } \\
\text { persepsi, makna } \\
\text { niatan, dan } \\
\text { kategorinya, } \\
\text { bahkan juga oleh } \\
\text { profesionalitasnya. }\end{array}$ \\
\hline $\begin{array}{l}\text { Elemen } \\
\text { ilokusi; tata } \\
\text { permainan } \\
\text { bahasa dan }\end{array}$ & $\begin{array}{l}\text { Ungkapan bahasa } \\
\text { adalah pernyataan } \\
\text { individu tentang } \\
\text { sesuatu yang } \\
\text { disampaikannya }\end{array}$ \\
\hline
\end{tabular}

\begin{tabular}{|c|c|}
\hline $\begin{array}{l}\text { implikasi } \\
\text { etisnya }\end{array}$ & $\begin{array}{l}\text { melalui suatu daya } \\
\text { khas, yang } \\
\text { membuat individu } \\
\text { tersebut merasa } \\
\text { telah bertindak } \\
\text { sesuai dengan apa } \\
\text { yang } \\
\text { dilakukannya. } \\
\text { Oleh karena } \\
\text { mengandung suatu } \\
\text { daya yang khas, } \\
\text { suatu ungkapan } \\
\text { bahasa selalu } \\
\text { berimplikasi } \\
\text { dengan masalah } \\
\text { etis. }\end{array}$ \\
\hline $\begin{array}{l}\text { Elemen } \\
\text { perlokusi; } \\
\text { efek } \\
\text { ungkapan } \\
\text { jurnalistik }\end{array}$ & $\begin{array}{l}\text { Ungkapan bahasa } \\
\text { menyebabkan efek } \\
\text { tertentu bagi } \\
\text { pendengarnya atau } \\
\text { pembacanya. Hal } \\
\text { ini dapat terjadi } \\
\text { sebagai dampak } \\
\text { dari fungsi bahasa } \\
\text { sebagai } \\
\text { pemengaruh. }\end{array}$ \\
\hline
\end{tabular}

\section{METODE}

Penelitian ini menggunakan metode penelitian deskriptif kualitatif dengan pendekatan studi kasus. Sumber data penelitian ini adalah berbagai tulisan meliputi judul berserta keterkaitan isi pada media massa online yang memuat pemberitaan kasus pelecehan seksual yang dilakukan Reynhad Sinaga. Penelitian dikulakukan selama dua pekan dengan cara mengambil data dari media massa online Indonesia. Pada penelitian ini data diambil dari berbagai sumber media massa online yang berbentuk laman. Selanutnya, peneliti mencari data kedekatan judul berita antara 
pemilihan diksi yang berbentuk sarkasme dengan kesesuaian isi pada isi berita tersebut. Setelah beberapa judul didapat peneliti mengklasifikasikan data berdasarkan kecurigaan peneliti terhadap ketidaksesuaian pemilihan diksi sarkasme dengan isi berita yang disusun oleh penulis berita yang menjadi alat penggiring ideologi kepada masyarakat umum.

Sejalan dengan pemaparan sebelumnya, waktu penelitian ini berjalan selama pekan tepatnya pada bulan januari 2019 sampai februari 2020. Pekan pertama dan kedua, peneliti melakukan proses pengumpulan data. Selain itu, mengamati perubahan berita berdasarkan perkembangan kasus pemberitaan kasus pelecehan seksual Reynhad Sinaga. Perubahan berita tersebut berdampak langsung pada proses analisis untuk melihat konteks berita dengan konteks perubahan pengiringan publik yang dilakukan oleh penulis berita.

Analisis data kualitatif yang dipakai dalam penelitian ini adalah Critical Discourse Analysis Norman Fairclough. Fairclough dalam (Krolokke dan Sorensen, 2006:52-53) menyatakan proses analisis texts ini sebagai microlevel, discourse practice sebagai mesolevel dan proses analisis sociocultural practice sebagai macrolevel. Menurut Fairclough, analisis teks ini disebut pula dengan linguistic analysis. Teks di sini dianalisis secara linguistik, dengan melihat kosakata, semantik dan tata kalimat. Fairclough juga memasukkan koherensi dan kohesi antarkata atau antarkalimat sehingga mem- bentuk pengertian dalam sebuah wacana.

Keterkaitan pemaparan metode dan alur penelitian tersebut dengan penelitian ini berada pada semua tataran linguistik yang nantinya akan dianalisis, dipakai untuk melihat beberapa masalah mengenai ideasional atau representasi yang merujuk pada representasi tertentu yang ingin ditampilkan penulis pada judul dan isi yang secara tidak langsung membawa muatan pengiringan publik. Bentuk representasi tersebut menurut Fairclough dianalisis dalam tiga hal tentang bagaimana penulis yang mewakili perseorangan, kelompok, dan juga sebuah gagasan yang coba ditunjukkan dalam bentuk sarkasme, dalam kombinasi judul serta dalam rangkaian antarkalimat dalam isi berita. Betuk representasi dalam anak kalimat, pemakai bahasa oleh penulis pada judul dan isi berita dihadapkan pada dua pilihan. Pertama, pada tingkat pilihan diksi. Kedua, pilihan yang didasarkan pada tingkat tata bahasa. Ketiga konteks ditampilkan sebagai sebuah tindakan, peristiwa, keadaan yang berusaha melakukan penggiringan publik, atau hanya sebagai proses mental yang dilakukan utuk menarik nitezen membaca laman yang dibuatnya.

\section{HASIL DAN PEMBAHASAN}

Berikut adalah gambaran kerangka analisis Fairclough dalam pemberitaan kasus pelecehan seksual yang dilakukan oleh Reynhard Sinaga. 


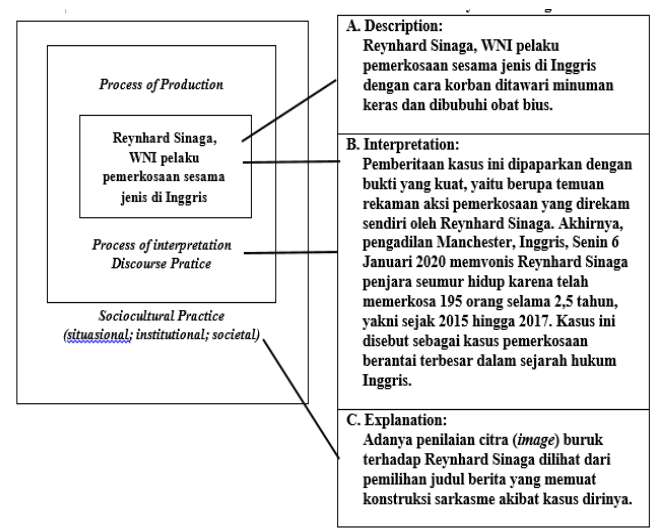

Gambar 1

Kerangka Analisis Fairclough dalam Pemberitaan Kasus Pelecehan Seksual Reynhard Sinaga

\section{1) Analisis Teks (Mikrostruktural)}

Berikut ini disajikan data penelitian ini berupa judul pemberitaan kasus Reynhard Sinaga.

\section{Tabel 2}

Data Judul Pemberitaan Pelecehan Seksual Reynhard Sinaga

\begin{tabular}{|c|c|c|}
\hline $\begin{array}{l}\text { Media } \\
\text { Online }\end{array}$ & $\begin{array}{l}\text { Ko } \\
\text { de }\end{array}$ & Judul Berita \\
\hline$\frac{\underline{\text { https://www }}}{\text { bbc.com/in }}$ & $\begin{array}{l}\text { (D } \\
01)\end{array}$ & $\begin{array}{l}\text { Para prialnal Ilr } \\
\text { korban } \text { Indondidil } \\
\text { perkosaan: } \\
\text { 'Saya ingin } \\
\text { Reynhard } \\
\text { Sinaga } \\
\text { menderita, } \\
\text { membusuk di } \\
\text { neraka, ia } \\
\text { menghancur- } \\
\text { kan satu }\end{array}$ \\
\hline
\end{tabular}

\begin{tabular}{|c|c|c|}
\hline & & $\begin{array}{l}\text { bagian hidup } \\
\text { saya' }\end{array}$ \\
\hline $\begin{array}{l}\frac{\text { https://www }}{\text { inews.id/ne }} \\
\text { ws/nasional/ } \\
\text { begini-cara- } \\
\text { reynard- } \\
\text { sinaga- }\end{array}$ & $\begin{array}{l}\text { (D } \\
02)\end{array}$ & $\begin{array}{l}\text { Begini Cara } \\
\text { Reynhard } \\
\text { Sinaga, } \\
\text { Predator Seks } \\
\text { Mencari } \\
\text { Mangsa di } \\
\text { Inggris }\end{array}$ \\
\hline $\begin{array}{l}\text { https://m.det } \\
\text { ik.com/news } \\
\text { /berita/d- } \\
4849421 / \text { pr } \\
\text { ofil- }\end{array}$ & $\begin{array}{l}\text { (D } \\
03)\end{array}$ & $\begin{array}{l}\text { Profil } \\
\text { Reynhard } \\
\text { Sinaga, } \\
\text { Predator Seks } \\
\text { yang Perkosa } \\
\text { 48 Pria di } \\
\text { Inggris }\end{array}$ \\
\hline 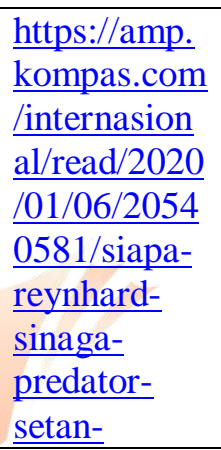 & $\begin{array}{l}\text { (D } \\
04)\end{array}$ & $\begin{array}{l}\text { Siapa } \\
\text { Reynhard } \\
\text { Sinaga, } \\
\text { "Predator } \\
\text { Setan" dalam } \\
\text { Kasus } \\
\text { Pemerkosaan } \\
\text { Terbesar di } \\
\text { Inggris? }\end{array}$ \\
\hline 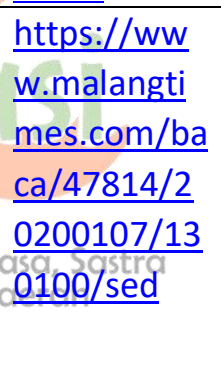 & $\begin{array}{l}\text { (D } \\
05)\end{array}$ & $\begin{array}{l}\text { Sederet Fakta } \\
\text { Mengerikan } \\
\text { Reynhard } \\
\text { Sinaga, } \\
\text { Pemerkosa } \\
\text { Berantai } \\
\text { Terbesar di } \\
\text { Dunia }\end{array}$ \\
\hline $\begin{array}{l}\frac{\text { https://m.ka }}{\text { skus.co.id/s }} \\
\text { how_post } / 5 \\
\text { e140650057 } \\
\text { 7a9628a1d3 } \\
\text { 3fa/? }\end{array}$ & $\begin{array}{l}\text { (D } \\
06)\end{array}$ & $\begin{array}{l}\text { Predator Sex } \\
\text { Asal Indonesia } \\
\text { Memerkosa } 48 \\
\text { Pria Inggris, } \\
\text { Di Hukum } \\
\text { Seumur Hidup }\end{array}$ \\
\hline
\end{tabular}




\begin{tabular}{|c|c|c|}
\hline $\begin{array}{l}\text { https://urban } \\
\text { jabar.com/2 } \\
\text { 020/01/07/r } \\
\text { eynhard- } \\
\underline{\text { sinaga- }} \\
\underline{\text { warga- }} \\
\text { depok- }\end{array}$ & $\begin{array}{l}\text { (D) } \\
07)\end{array}$ & $\begin{array}{l}\text { Reynhard } \\
\text { Sinaga: Warga } \\
\text { Depok yang } \\
\text { Jadi Predator } \\
\text { Seks Terbesar } \\
\text { di Inggris }\end{array}$ \\
\hline $\begin{array}{l}\frac{\text { https://Www }}{\text { lensaindone }} \\
\underline{\text { sia.com/202 }} \\
\underline{\text { 0/01/09/was }} \\
\text { padai- }\end{array}$ & $\begin{array}{c}\text { (D) } \\
08)\end{array}$ & $\begin{array}{l}\text { Waspadai } \\
\text { minuman obat } \\
\text { bius "Predator } \\
\text { Seksual } \\
\text { Setan" ala } \\
\text { Reynhard } \\
\text { Sinaga }\end{array}$ \\
\hline $\begin{array}{l}\frac{\text { https://www }}{\text { kompasiana }} \\
\text { com/fery50 } \\
\text { 973/5e140a } \\
\underline{\text { da097f364e }} \\
\underline{88520 \mathrm{~b} 52 / \mathrm{p}} \\
\text { redator-sex- } \\
\text { wni- }\end{array}$ & $\begin{array}{l}\text { (D) } \\
09)\end{array}$ & $\begin{array}{l}\text { Predator Sex, } \\
\text { WNI } \\
\text { Pemerkosa } \\
190 \text { Pria di } \\
\text { Inggris, } \\
\text { Dihukum } \\
\text { Seumur Hidup }\end{array}$ \\
\hline $\begin{array}{l}\text { https://yout } \\
\text { u.be/2Wcu3 } \\
\text { vLrlUM }\end{array}$ & $\begin{array}{l}\text { (D) } \\
10)\end{array}$ & $\begin{array}{l}\text { "Predator } \\
\text { Seksual } \\
\text { Setan" } \\
\text { Reynhard } \\
\text { Sinaga } \\
\text { Akhirnya } \\
\text { Dihukum } \\
\text { Penjara } \\
\text { Seumur Hidup }\end{array}$ \\
\hline $\begin{array}{l}\frac{\text { https://ww }}{\text { w.kupasonli }} \\
\text { ne.com/202 } \\
\text { 0/01/liberali } \\
\text { sme- } \\
\text { melahirkan- }\end{array}$ & $\begin{array}{l}\text { (D) } \\
11)\end{array}$ & $\begin{array}{l}\text { Liberalismelidih } \\
\text { Melahirkannesi申 } \\
\text { Generasi } \\
\text { Predator } \\
\text { Seksual Setan }\end{array}$ \\
\hline $\begin{array}{l}\frac{\text { https://jaten }}{\text { g.tribunnew }} \\
\text { s.com/2020/ } \\
\text { 01/07/berita } \\
\text {-lengkap- }\end{array}$ & $\begin{array}{l}\text { (D) } \\
12)\end{array}$ & $\begin{array}{l}\text { Reynhard } \\
\text { Sinaga } \\
\text { Penjahat } \\
\text { Kelamin yang }\end{array}$ \\
\hline
\end{tabular}

\begin{tabular}{|c|c|c|}
\hline $\begin{array}{l}\text { reynhard- } \\
\text { sinaga- }\end{array}$ & & $\begin{array}{l}\text { Dijuluki } \\
\text { Predator Setan } \\
\text { Divonis } \\
\text { Seumur Hidup }\end{array}$ \\
\hline $\begin{array}{l}\frac{\text { https://m.d }}{\text { etik.com/in }} \\
\frac{\text { et/cyberlife }}{\Delta d-}\end{array}$ & $\begin{array}{l}\text { (D) } \\
13)\end{array}$ & $\begin{array}{l}\text { Jadi Predator } \\
\text { Seks, } \\
\text { Reynhard } \\
\text { Sinaga Disorot } \\
\text { Netizen Dunia }\end{array}$ \\
\hline $\begin{array}{l}\frac{\text { https://www. }}{\text { insertlive.co }} \\
\text { m/hot- } \\
\text { gossip/2020 } \\
\underline{0107162844-} \\
\underline{7-}\end{array}$ & $\begin{array}{l}\text { (D } \\
14)\end{array}$ & $\begin{array}{l}\text { Terbongkar, Isi } \\
\text { Chat Biadab } \\
\text { Reynhard } \\
\text { Sinaga soal } \\
\text { Perkosa } \\
\text { Ratusan Pria }\end{array}$ \\
\hline
\end{tabular}

Berdasarkan tabel data penelitian di atas, dapat diketahui bahwa pemilihan diksi pada beberapa judul pemberitaan kasus tersebut jelas mengindikasikan adanya beragam bentuk konstruksi sarkasme yang ditujukan kepada Reynhard Sinaga, sebagai pelaku tindakan pemerkosaan berantai di Inggris.

Berikut ini Data (D01): Para pria korban perkosaan: 'Saya ingin Reynhard Sinaga menderita, membusuk di neraka, ia ahmenghancurkan satu bagian hidup sayas Dilihat dari sintaksisnya, Data (D01) dinilai sebagai judul yang unik dan menarik, karena tidak seperti judul pada umumnya, yakni pemilihan judul bahasanya sengaja dipilih berupa bentuk kalimat/tuturan langsung dari korban pemerkosaan. Dari segi semantik, tuturan langsung tersebut menunjukkan adanya harapan, karena ditandai adanya adverbia "ingin". Dalam tuturan ini, 
tentunya pengungkapan harapan tersebut lebih mengacu pada makna bahwa para korban "menyumpahi" kepada pelaku pemerkosaan. Dalam KBBI V, "menyumpahi" artinya mengeluarkan kata-kata kotor berkalikali. Hal ini secara eksplisit jelas terlihat pada judul pemberitaan data (1): Para pria korban perkosaan: 'Saya ingin Reynhard Sinaga menderita, membusuk di neraka, ia menghancurkan satu bagian hidup saya'.

Dilihat dari segi pragmatik, kehadiran tuturan yang bermuatan sarkasme tersebut dapat dimaklumi sebagai bentuk amarah atas perlakuan pelecehan seksual yang menimpa para korban itu. Hal ini sejalan dengan pendapat Wijana \& Rohmadi (2013:109) yang menyatakan bahwa dalam situasi marah, para pemakai bahasa memanfaatkan berbagai kata makian, di samping kata-kata kasar atau sindiran halus untuk mengekspresikan segala bentuk ketidaksenangan, kebencian, atau ketidakpuasannya terhadap situasi yang tengah dihadapinya.

Data D02: Begini Cara Reynhard Sinaga, Predator Seks Mencari Mangsa di Inggris. Dilihat dari aspek sintaksis, Data (D02) merupakan judut berita yang memuat konstruksi sarkasme berbentuk klausa, yakni "Predator Seks Mencari Mangsa di Inggris". Dalam klausa itu, terdapat kata majemuk, yaitu "Predator Seks" yang dapat juga dikatakan sebagai bentuk idiom jika dilihat dari segi semantiknya. Idiom "Predator Seks" pun terlihat pada data (D03) "Profil Reynhard Sinaga, Predator Seks yang Perkosa 48 Pria di Inggris"; data
(D06) "Predator Sex Asal Indonesia Memerkosa 48 Pria Inggris, Di Hukum Seumur Hidup"; data (D07) "Reynhard Sinaga: Warga Depok yang Jadi Predator Seks Terbesar di Inggris"; data (D09) "Predator Sex, WNI Pemerkosa 190 Pria di Inggris, Dihukum Seumur Hidup"; dan data (D13) "Jadi Predator Seks, Reynhard Sinaga Disorot Netizen Dunia”.

Jika dilihat dari makna leksikalnya, kata "predator" artinya binatang yang hidupnya memangsa binatang lain; hewan pemangsa hewan lain dan kata "seks" definisinya jenis kelamin; hal yang berhubungan dengan alat kelamin seperti sanggama; berahi (KBBI V). Namun, dicermati dari aspek semantiknya, idiom "Predator Seks" dalam judul berita Data (D02), (D03), (D06), (D07), (D09) dan (D13) dapat diartikan sebagai pelaku pemerkosaan yang berhasil menodai banyak korbannya, dalam hal ini adalah Reynhard Sinaga.

Tindakan asusilanya ini dikecam oleh berbagai pihak hingga berita ini menjadi sorotan di dunia. Perilaku seksualnya dianggap sangat keji dan tidak wajar sebagai manusia, sehingga tak heran jika dalam judul beritanya digunakan bahasa yang memiliki konstruksi sarkasme dengan menganalogikan sosok Reynhard Sinaga dengan binatang, melalui pemilihan kata "predator" pada idiom "Predator Seks". Maka dari itu, jelaslah bahwa penggunaan idiom "Predator Seks" mengindikasikan adanya sebuah ungkapan/ejekan/sindiran yang kasar.

Sementara itu, muncul juga bentuk konstruksi sarkasme yang dirasa lebih tinggi lagi tingkat kekasarannya, 
karena adanya kombinasi pemilihan kata "predator", kata "setan", dan kata "seksual". Hal ini secara implisit memperlihatkan bahwa beberapa judul berita menunjukkan ungkapan sindiran yang sangat kasar terhadap Reynhard Sinaga, pelaku kejahatan seksual itu. Untuk lebih jelasnya, perhatikan data D04 berikut:

\section{Siapa Reynhard Sinaga, \\ "Predator Setan" dalam Kasus \\ Pemerkosaan Terbesar di \\ Inggris? \\ Waspadai minuman obat bius \\ “Predator Seksual Setan" ala \\ Reynhard Sinaga, Data (D08) \\ "Predator Seksual Setan" \\ Reynhard Sinaga Akhirnya \\ Dihukum Penjara Seumur \\ Hidup, Data (D10) \\ Liberalisme Melahirkan \\ Generasi Predator Seksual Setan, \\ Data (D11) \\ Reynhard Sinaga Penjahat \\ Kelamin yang Dijuluki Predator \\ Setan Divonis Seumur Hidup, \\ Data (D12)}

Pada Data (D04), ditemukan konstruksi sarkasme berupa kata majemuk bentuk idiom "Predator Setan" dan pada Data (D08), (D10), dan (D11) ditemukan bentuk idiom "Predator Seksual Setan". Sementara itu, Data (D12) mengindikasikan hadirnya konstruksi sarkasme berbentuk frasa, yakni "Reynhard Sinaga Penjahat Kelamin yang Dijuluki Predator Setan Divonis Seumur Hidup". Dari Data (D12), diketahui ada dua bentuk idiom yang bernuansakan sarkasme, yakni "Penjahat Kelamin" dan "Predator Setan". Seperti yang diketahui bahwa secara semantik, idiom "Penjahat Kelamin" disematkan bagi orang yang melakukan tindakan kejahatan yang berkaitan dengan perusakan alat kelamin sebagai alat vital manusia.

Penggunaan kata "setan" dalam kombinasi bentuk idiom-idiom di atas, menunjukkan konstruksi sarkasme yang sangat kuat. Dilihat dari makna leksikalnya, kata "setan" didefinisikan sebagai roh jahat yang selalu menggoda manusia supaya berlaku jahat; kata untuk menyatakan kemarahan; sumpah serapah; kiasan untuk orang yang sangar buruk perangainya (KBBI V). Oleh karena itulah, secara eksplisit sangat jelas bahwa julukan "Predator Setan" memang ditujukan untuk Reynhard Sinaga sebagai pelaku kejahatan yang menyerang/merusak alat kelamin manusia sehingga disebut "Penjahat Kelamin" sekaligus dijuluki "Predator Setan".

Pada penelitian ini, ditemukan pula konstruksi sarkasme berupa kata majemuk berbentuk Idiom lainnya, yaitu "Pemerkosa Berantai", seperti yang terlihat pada Data (D05): "Sederet Fakta Mengerikan Reynhard Sinaga, Pemerkosa Berantai Terbesar di Dunia". Secara leksikal, kata "pemerkosa" adalah orang yang memerkosa;"rqata "memerkosa" itu sendiri artinya memaksa dengan kekerasan; menggagahi; dan kata "berantai" artinya memakai rantai; bersambung; saling berkait (KBBI V).

Dengan terbentuknya idiom "Pemerkosa Berantai", maka maknanya adalah pemerkosa yang melakukan kekerasan seksualnya dengan aksi yang bersambung atau berturut-turut mulai dari satu korban 
hingga korban-korban berikutnya. Dalam kaitan ini, kasus pemerkosaan oleh Reynhard Sinaga menghebohkan dunia, karena jumlah korbannya dinilai sangat fantastis, seperti yang dinarasikan dalam kutipan berita berikut ini.

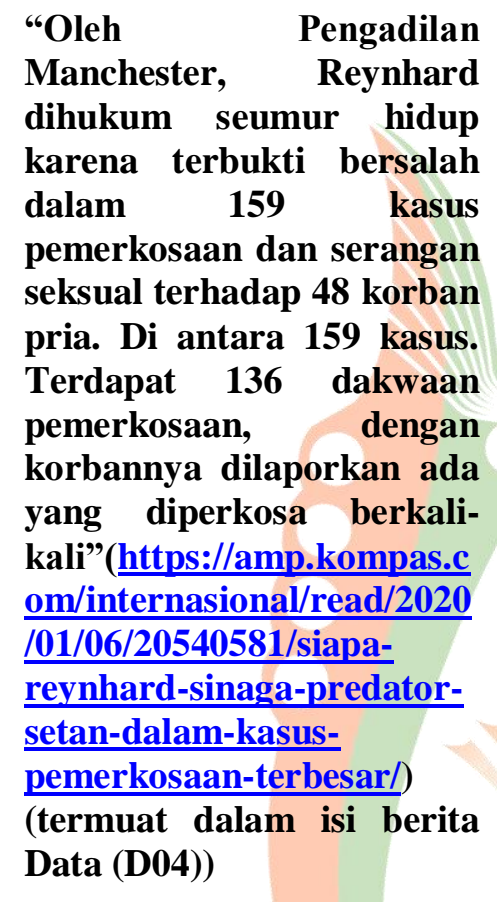

Sementara itu, Data (D14), yakni "Terbongkar, Isi Chat Biadab Reynhard Sinaga soal Perkosa Ratusan Pria" mengandung bentuk frasa "Isi Chat Biadab Reynhard Sinaga" yang bermuatan sarkasme, karena terdapat kata "biadab". Seperti yang diketahui bahwa kata "biadab" secara leksikal memiliki makna belum beradab; tidak tahu adat (sopan santun); kurang ajar; kejam (KBBI V). Oleh sebab itu, tak heran jika dalam kehidupan sehari-hari, terkadang ditemukan kata "biadab" sebagai kata makian yang dimanfaatkan untuk mengungkapkan rasa marah kepada orang yang berperilaku kejam atau kurang ajar.

Sehubungan dengan hal tersebut, perilaku biadab Reynhard Sinaga terlihat dari isi chat-nya yang dimuat dalam narasi berita di bawah ini: "Isi percakapan mereka terbilang sangat bejat dan benar-benar memperlihatkan kelakukan menyimpang seksual Reynhard Sinaga... Lalu, Reynhard membalasnya dengan membeberkan metode yang ia gunakan untuk melumpuhkan korban agar mereka tidak sadar sebelum diperkosa. "Ramuan sihir hitam," tulis Reynhard. Ramuan yang dimaksud oleh si predator terbuas dunia ini adalah GHB atau gamma-hydroxybutyrate yang dicampur Reynhard ke minuman korban, senyawa tersebut mampu melumpuhkan kesadaran seseorang." (https://www.insertlive.com/hotgossip/20200107162844-7-

75442/terbongkar-isi-chat-biadabreynhard-sinaga-soal-perkosaratusan-pria) (termuat dalam isi berita Data (D14))

Berdasarkan isi berita yang disajikan di atas, perilaku kejam Reynhard Sinaga dikemukakan secara terperinci terkait metode yang digunakannya untuk melumpuhkan kesadaran korban sebelum diperkosa. Oleh karena itu, dapat dipahami alasan kemunculan konstruksi sarkasme berupa penggunaan diksi "biadab" di dalam struktur bahasa judul berita Data (D14), yakni “Terbongkar, Isi Chat Biadab Reynhard Sinaga soal Perkosa Ratusan Pria". 


\section{2) Analisis Discourse Practice (Mesostruktural)}

Pada subbab ini peneliti akan mendeskripsikan unsur mesostruktural kontruksi yang dilakukan dalam proses penggiringan opini publik. Pada proses ini penulis berita mempunyai beberapa teknik dalam upaya pengungkapan gagasan, baik itu dapat berupa pemilihan diksi pada judul berita, gambar sebagai latar profil konteks berita atau proses pemaknaan yang mengarah kepada homogenitas.

Pada kasus pemberitaan ini proses mesostruktural pemberitaan relatif sama. Penggunaan diksi predator digunakan oleh beberapa penulis. Diksi ini menurut peneliti paling tepat menunjukan nilai sarkasme pada sebuah diksi. Seperti yang telah dijelaskan pada subbab sebelumnya nilai predator tersebut jika dipisahkan menjadi sebuah bentuk diksi yang terpisah dari konteks sangat tidak tepat untuk mewakili konteks pelaku yang notaben sebagai manusia diarahkan kepada bentuk hewan atau tanaman.

Pemilihan diksi itu pun tidak terlepas dari sifat yang ada pada media sosial, sifat hashtag atau tanda pagar pada sebuah diksi akan mempercepat berita tersebut muncul dalam beberapal laman sebagai berita utama, serta dalam segi komersil akan diuntungkan oleh iklan yang muncul. Hal tersebut dapat terlihat dari empat belas data, diksi sarkasme predator muncul sebanyak sepuluh data.

Pada unsur profil latar pemberitaan media online terdapat beberapa model pemilihan tampilan yang dilakukan, mulai dari foto terdakwa, karikatur, meme, hingga gambar kartun yang multitafsir. Misal pada tampilan profil yang dimunculkan oleh https://tirto.id/jika-kasus-reynhardsinaga-terjadi-di-indonesia-ermu

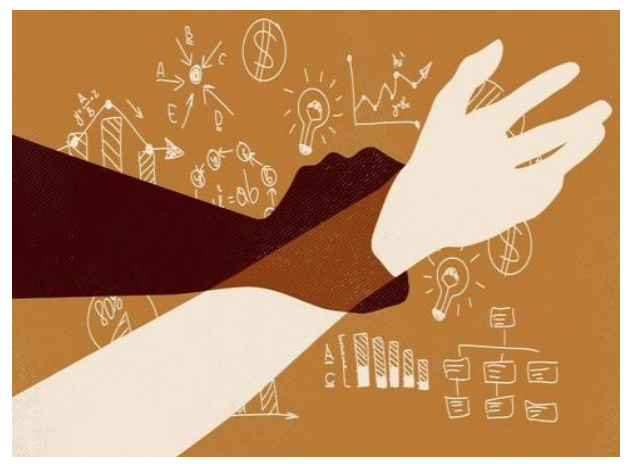

Gambar Data 1

Pada gambar tersebut, pembaca tidak akan dengan mudah menginterpretasi, perlu dianalisis, bahkan dianalisis secara mendalam dengan dengan mengunakan pendekatan semiotika dalam ilmu bahasa. Berkaitan dengan hal tersebut peneliti berupaya mendeskripsikan beberapa tanda yang muncul pada tampilan ini dengan teori ideologi William. Pada tampilan ini muncul tampak tanda-tanda balok persentase, lampu (tanda ide), sebuah rumus aritmatika, tanda salah satu mata uang dan genggaman tangan mengarahkan kepada sebuah ideologi yang homogen, bahwa kasus pemerkosaan ini dilakukan dengan sebuah rencana yang matang, bukan sebuah kebetulan.

Faktor tampilan balok persentase menggambarkan korban pemerkosaan yang mengalami peningkatan dalam jangka waktu tertentu, selain itu tampilan salah satu tanda mata uang dihadirkan sarat akan makna bahwa tidak semua korban pelecehan seksual yang dilakukan Reynhard Sinaga atas 
unsur pemaksaan, mungkin saja ada unsur pembayaran jasa akan layanan seksual yang diberikan oleh korban kepada pelaku.

Berbeda dengan tampilan profil gambar berita yang ditampilkan oleh media online berikut. https://m.kaskus.co.id/show post/5e1 406500577a9628a1d33fa/?child id=5 e1410b98012ae7dd5000f05\&ref=pro file\&med=post.

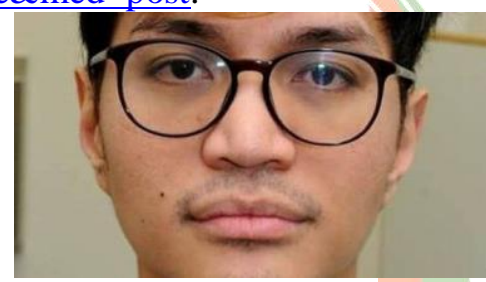

Gambar Data 2

Serupa dengan profil gambar berita yang ditampilkan oleh media online https://www.google.com/search?safe =strict $\&$ biw $=1366 \& \mathrm{bih}=657 \& \mathrm{tbm}=$ is ch\&sxsrf=ACYBGNS6n

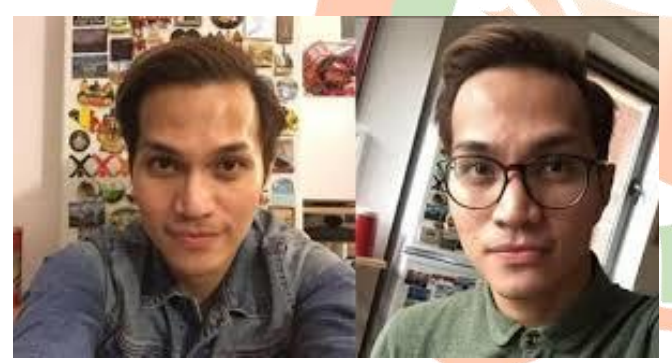

Gambar Data 3
Indonesia yang memiliki paras yang dapat dikriteriakan menarik atau rupawan dengan gaya rambut dan berpakaian yang modis atau update.

Pada data ini peneliti beranggapan bahwa sebuah ideologi hadir harus disertai oleh subjek. Hal ini sejalan dengan pendapat Althuseer dalam (Fiske, 1990) Menjelaskan konsep tentang subjek dan ideologi. Beliau memandang Ideologi selalu memerlukan subjek, sebaliknya subjek pasti memerlukan ideologi. Ideologi muncul berdasarkan hasil rumusan individu-individu tertentu, tetapi keberlakuannya menuntut tidak hanya kelompok yang bersangkutan.

Berdasarkan keterkaitan gambar tampilan berita dan pemaparan teori Althuseer dapat dideskripsikan bahwa terdapat sebuah pembentukan atau pengiringan ideologi kepada pembaca bahwa orang-orang yang memiliki prilaku seks menyimpang adalah seorang yang harus memiliki wajah menarik dan rupawan, gaya rambut dan berpakaian yang modis, juga memilliki kelebihan dalam segi ekonomi. Sedangkan masalah pelaku sebagai orang yang berkebangsaan Indonesia hanya dijadikan sebagai sebuah fenomena pada sebuah kasus Jurnal Ilmiahyang menguak pada jumlah Pendidikan pemerkosaan sesama jenis yang

Pada kedua tampilan ini media online menampilkan gambar profil berita yang sangat mudah ditafsirkan oleh pembaca, penulis hanya menampilkan subjek pelaku pelecehan tersebut, penulis memberikan gambaran foto pelaku yang identik sekali dengan karakter orang Indonesia. Selain itu pada gambar kedua muncul juga karakter orang terbesar sepanjang sejarah.

\section{3) Analisis Sosiocultural Practice (Makrostruktural)}

Analisis Makrostruktural adalah unsur terakhir yang akan peneliti deskripsikan pada penelitian ini. Berawal dari pemaparan (Fairclough, 2003: 25) yang menyatakan Social practice can be seen as articulations 
of different types of social element which are associated with particular areas of social life." Atau apabila di parafrasekan akan mengandung arti bahwa praktik sosiokultural adalah sebuah dimensi yang secara tidak langsung memiliki hubungan dengan konteks yang berada di luar teks seperti konteks sosial, baik itu yang berupa situasional maupun institusional.

Peneliti beranggapan bahwa ada sebuah ketidakterkaitan antara sebuah pemberitaan dengan situasi atau konteks yang berada dibelakang kasus tersebut. Misal pada beberapa pemberitaan disebutkan bahwa Reynhard Sinaga adalah seorang mahasiswa asal Indonesia yang sedang mengampu studi s3 atau doctoral, misal beberapa judul pemberitaan di bawah ini.

\section{Tabel 3}

Judul pemberitaan yang mengandung Social practice

\begin{tabular}{|c|c|}
\hline Judul & Media online \\
\hline $\begin{array}{l}\text { Reynhard } \quad \text { Sinaga, } \\
\text { Mahasiswa S3 RI di } \\
\text { Inggris Diduga Perkosa } \\
\text { 190 Pria }\end{array}$ & $\underline{\text { https://www.id }}$ \\
\hline $\begin{array}{l}\text { Reynhard Sinaga si } \\
\text { Pelakur Pemerkosa } \\
\text { Puluhan Pria yang } \\
\text { Divonis Seumur Hidup di } \\
\text { Manchester, Mahasiswa } \\
\text { S3 dan Aktif di Gereja }\end{array}$ & $\begin{array}{l}\text { https://plus kap } \\
\text { anlagi.com/ }\end{array}$ \\
\hline $\begin{array}{l}\text { Kasus Reynhard Sinaga } \\
\text { yang Dijatuhi Hukuman } \\
\text { Seumur Hidup, Lagi } \\
\text { Kuliah S3 di Inggris }\end{array}$ & $\begin{array}{l}\text { https://news.ok } \\
\text { ezone.com/ }\end{array}$ \\
\hline
\end{tabular}

\begin{tabular}{ll|l} 
Fakta Predator Seks & https://www.in \\
Reynhard Sinaga, & ews.id/news/int \\
Mahasiswa S3 yang & ernasional \\
Dijuluki Monster &
\end{tabular}

Berdasarkan contoh-contoh judul pemberitaan tersebut dapat terlihat beberapa penulis membuat judul dengan memberikan muatan sosial practice di dalamnya. Penulis memberikan gambaran bahwa seseorang yang memiliki gelar akademis tinggi mempunyai prilaku seks yang menyimpang. Hal ini secara tidak langsung akan memberikan sebuah setigma perubahan kea arah yang negatif kepada masyarakat umum tentang nilai religius, nilai logis hingga nilai moralitas yang dimiliki oleh seorang yang memiliki gelar akademik tinggi.

Sebuah gelar akademis di bidang kependidikan dianggap sebagai sebuah kebanggaan bagi pemiliknya ataupun bagi keluarganya, di indonesia seseorang yang dapat mendapatkan gelar sekelas sarjana saja dianggap sebagai seseorang yang mempunyai nilai lebih, baik itu dari sudut pandang pemikiran, kompetensi dan sudah jelas akan memperoleh nilai prestise lebih tinggi dari masyarakat sekitanya. Hal ini tentunya secara tidak langsung akan memunculkan setigma dari masyarakat umum ketika membaca beberapa judul yang serupa seperti yang peneliti paparkan sebelumnya

Selain itu Social practice yang terdapat pada judul pemberitaan secara online tentang kasus pelecehan seksual yang dilakukan oleh Reynhard Sinaga menyerang salah satu universitas ternama yang ada di 
Indonesia. Universitas di mana semua calon mahasiswa bercita-cita untuk dapat menempuh pendidikan di universitas tersebut. Hal ini dapat terlihat pada judul pemberitaan yang di munculkan pada laman https://www.tribunnews.com/ yang berjudul Reynhad Sinaga, Dikenal Pintar saat Kuiah di UI dan Mudah Bergaul, Lahir dari Keluarga Mapan. Sama seperti sosial practice yang muncul sebelumnya, judul pemberitaan ini memberikan setigma kepada kampus tersebut, bahkan alumi juga keseluruhan civitas yang berada pada kampus tersebut. ini sudah jelas akan menjatuhkan citra dari Universitas Indonesia yang selama ini adalah sebuah kampus dengan memiliki prestise paling tinggi di antara universitas lain yang ada di Indonesia.

Keseluruhan penjelasan tersebut sesuai dengan yang dipaparkan oleh Eriyanto (2003:321) yang menyatakan sebuah konteks di sini bisa berarti konteks situasi, atau luasnya adalah konteks dari praktik sebuah institusi media sendiri tetapi juga dalam hubungannya terhadap masyarakat atau budaya politik tertentu. Contohnya budaya media, politik media atau ekonomi media tertentu yang mempengaruhi teks yang dihasilkannya.

Analisis dimensi ini dapat menggambarkan bagaimana kekuatan-kekuatan yang ada dalam masyarakat memaknai dan menyebarkan ideologi yang dominan kepada masyarakat. Selain itu stigma tersebut dapat dikaitkan secara langsung dengan konsep hegomoni Antonio Gramsci. Gramsci dalam (Setiawan,
2011:15) mengkonstruksi suatu teori yang menekankan bagaimana penerimaan kelompok yang didominasi oleh kehadiran kelompok dominan berlangsung dalam suatu proses yang damai, tanpa tindakan kekerasan. Media massa dapat menjadi sarana di mana satu kelompok mengukuhkan posisinya dan merendahkan kelompok lainnya.

\section{PENUTUP}

\section{Simpulan}

Berdasar pada proses analisis data yang dilakukan peneliti terhadap lebih dari 20 judul pemberitaan di media massa online, maka peneliti dapat menarik simpulan bahwa dalam proses pembuatan judul berita penyimpangan dan kekerasan seksual yang dilakukan Reynhad Sinaga, media massa online memiliki kontruksi tertentu. Pembuat judul berita sengaja menggunakan diksi yang berbentuk sarkasme. Hal ini dikarenakan untuk memberikan gambaran kepada pembaca betapa mengerikannya kasus pelecehan seksual yang terjadi. Berkaitan dengan hal tersebut akan muncul sebuah efek bentuk sarkasme yang menimbulkan bentuk referen multitafsir dalam proses pemaknaannya.

Sélanjutnya, refleksi kontruksi ideologi media massa online pada pemberitaan kasus pemerkosaan sesama jenis yang dilakukan oleh Reynhad Sinaga memberikan beberapa stigma terhadap masyarakat umum yaitu dari tampilan pelaku yang menarik dan rupawan, gaya berbusana yang modis, dan keadaan ekonomi yang berada pada taraf menengah ke atas. Selain itu teori hegomoni pada 
kasus pemberitaan ini, penulis berita berupaya memberikan stigma tentang tingkat pendidikan yang tinggi, studi lanjut di universitas di luar Indonesia dan dengan gamlang memberikan relevansi terhadap salah satu kampus ternama di Indonesia.

\section{DAFTAR PUSTAKA}

Ansori, Dadang. 2017. Analisis Wacana Teori, Aplikasi dan Pembelajaran. Bandung: UPI Press.

Brown, G. dan Yule, G. 1996. Analisis Wacana. Jakarta: Gramedia Pustaka Utama.

Cenderamata, R. C. \& Darmayanti, N. 2019. Analisis Wacana Kritis Fairclough pada Pemberitaan Selebriti di Media Daring. Jurnal Literasi. Volume 3, Nomor 1. Diakses dari https://jurnal.unigal.ac.id/index.p hp/literasi/article/view/1736, pada tanggal 23 Januari 2020.

Crews, Douglas. \& Crawford, Marcus. 2015. Exploring the Role of Being Out on a Queer Person's SelfCompassion. Journal of Gay \& Lesbian Social Services Vol. 27 (No. 2), pp. 172-186.

Eriyanto. 2003. Analisis Framing: Konstruksi Ideologi, dan Politiki I Media. Yogyakarta: LKiS. Pendid

Fairclough, Norman. 1989. Language and Power. New York: Addison Wesley Longman. Fairclough,

Fairclough, Norman. 1995. Media Discourse. London: Edward Arnold.

Fairclough, Norman. 2003. Critical Discourse Analysis in Transdisciplinary Research. London: Edward Arnold.
Fiske, John. 1990. Introduction to Communication Studies (Second Edition). London and New York: Routledge.

Kress, G. 1984. Linguistik and Ideological Transformations in News Reporting: Language, Image, Media (Davis, H. Walton, P., eds). England: Basic Blackwell.

Setiawan, Budiyanto. 2011. Analisis Wacana Kritis Pemberitaan Kekerasan Berbasis Gender: Jurnal Ilmiah Komunikasi Vol 2, No 1 .

Sorensen, Anne Scott dan Charlotte Krolokke. 2006. Gender Communication Theories and Analyses. Thousand Oaks. California: Sage Publications, Inc.

Tjumano, Konglomerasi Media Massa, Kompas, 8 September 2013.

Triadi, Rai Bagus, Firman Aziz. Kontruksi Media Pada Politikus Wanita: Judul Pemberitaan Kasus Hoaks Tokoh Politik Perempuan Pada Media Massa Online Indonesia. Jurnal Dieksis, Vol 11, no 2. 2019 di akses dari http:// .ac.id/index.php/Deiksis/ ricle/view/3636. Diakses pada 27 Januari 2019

Wibowo, W. 2009. Мепијu Jurnalisme beretika, Peran bahasa, Bisnis, dan Politik di Era Mondial. Jakarta: Kompas 25-30 Jurnal dengan 5 jurnal dari Gema Online.

Wijana, I.D. Putu \& Rohmadi, M. 2013. Sosiolinguistik: Kajian Teori dan Analisis. Yogyakarta: Pustaka Pelajar.

Wodak, R. and Chilton, P. 2005. A New Agenda in (Critical) 
Discourse Analysis. Amsterdam:

John Benj amnis Publishing.

Jurnal Ilmiah

Pendidikan Bahasa, Sastra

Indonesia dan Daerah 